\title{
Gastrointestinal injury associated with NSAID use: a case study and review of risk factors and preventative strategies
}

This article was published in the following Dove Press journal:

Drug, Healthcare and Patient Safety

22 January 2015

Number of times this article has been viewed

\section{Jay L Goldstein' \\ Byron Cryer ${ }^{2}$}

'Department of Medicine, NorthShore University HealthSystem, Evanston, IL, USA; ${ }^{2}$ Division of Gastroenterology, University of Texas Southwestern Medical Center and Dallas VA Medical Center, Dallas, TX, USA
Correspondence: Jay L Goldstein Department of Medicine, North Shore University HealthSystem, 2650 Ridge Avenue, Evanston, IL 6020I, USA Tel +l $8475702510 ;+$ I 8475702615 Fax +l 8475702905

Email jgoldstein@northshore.org
Abstract: Nonsteroidal anti-inflammatory drugs (NSAIDs) are effective anti-inflammatory and analgesic agents and are among the most commonly used classes of medications worldwide. However, their use has been associated with potentially serious dose-dependent gastrointestinal (GI) complications such as upper GI bleeding. GI complications resulting from NSAID use are among the most common drug side effects in the United States, due to the widespread use of NSAIDs. The risk of upper GI complications can occur even with short-term NSAID use, and the rate of events is linear over time with continued use. Although gastroprotective therapies are available, they are underused, and patient and physician awareness and recognition of some of the factors influencing the development of NSAID-related upper GI complications are limited. Herein, we present a case report of a patient experiencing a gastric ulcer following NSAID use and examine some of the risk factors and potential strategies for prevention of upper GI mucosal injuries and associated bleeding following NSAID use. These risk factors include advanced age, previous history of GI injury, and concurrent use of medications such as anticoagulants, aspirin, corticosteroids, and selective serotonin reuptake inhibitors. Strategies for prevention of GI injuries include anti-secretory agents, gastroprotective agents, alternative NSAID formulations, and nonpharmacologic therapies. Greater awareness of the risk factors and potential therapies for GI complications resulting from NSAID use could help improve outcomes for patients requiring NSAID treatment.

Keywords: side effects, ulcer, GI bleed, NSAID, gastrointestinal

\section{Case study}

A 53-year-old otherwise healthy female was admitted to the emergency department following two bouts of hematemesis and a single melenic stool. She denied abdominal pain or discomfort and reported no personal or family history of gastric ulcer. The patient reported being prescribed naproxen $500 \mathrm{mg}$ twice daily for the 2 days prior for an ankle sprain. On examination, the patient was hypotensive in the supine position, with a blood pressure of $90 / 30 \mathrm{mmHg}$, and was tachycardic, with a heart rate of 130 beats per minute. Abdominal examination was benign without tenderness. Hemoglobin was $10.2 \mathrm{~g} / \mathrm{dL}$ and hematocrit was 33.4\%; all other evaluated laboratory values were within normal limits. Endoscopy revealed a $1 \times 1 \mathrm{~cm}$ hemorrhagic gastric ulcer in the antrum with a visible vessel (Figure 1), which was cauterized at the time of endoscopy. Biopsies of the antrum and body were negative for Helicobacter pylori. Cautery was successful, and the patient was treated with an intravenous proton-pump inhibitor (PPI) and remained hospitalized for observation and to evaluate for rebleeding. During hospitalization, the patient was transitioned to an oral PPI. After 2 days 


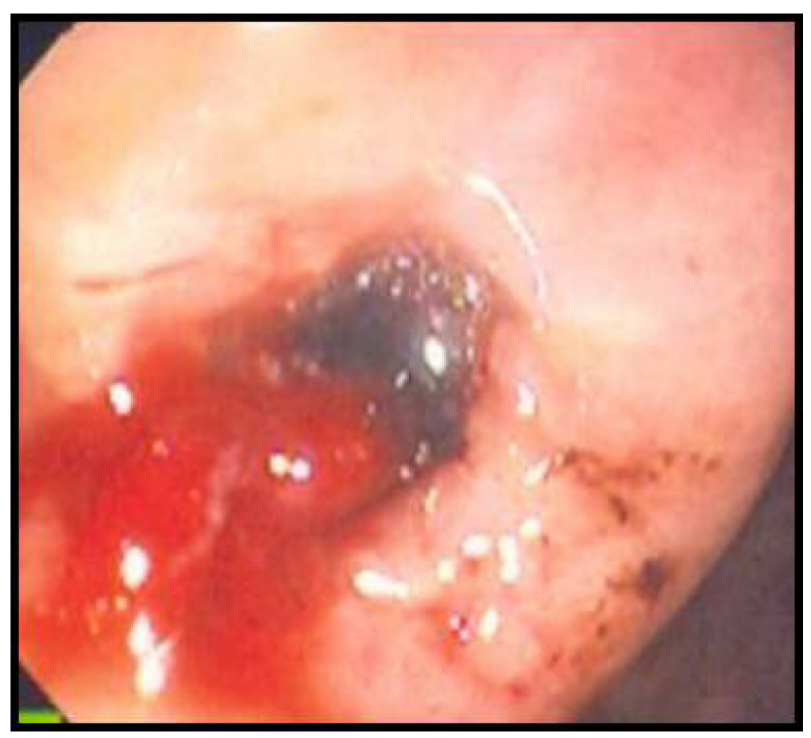

Figure I Endoscopic image of a $|\times| \mathrm{cm}$ hemorrhagic gastric ulcer in the antrum with a visible vessel revealed by endoscopy.

Note: Endoscopy is from a 53 -year-old woman presenting to the emergency department following two bouts of hematemesis and a melenic stool.

without evidence of rebleeding and with the patient's vital signs returning to normal, she was discharged home with an oral PPI. Her naproxen was not continued.

\section{Nonsteroidal anti-inflammatory drug use and incidence of complications Prevalence of nonsteroidal anti-inflammatory drug use}

Adequate pain management is a widespread clinical concern, and both prescription and over-the-counter (OTC) nonsteroidal anti-inflammatory drugs (NSAIDs) are frequently used for pain relief. ${ }^{1}$ NSAID use may also be increasing, as indicated by a 2010 National Health Interview Survey (NHIS) that found that $12.8 \%$ of adults in the United States were taking NSAIDs at least three times a week for 3 months, representing an increase of over $40 \%$ compared with the results of a similar interview in $2005 .^{2}$ This volume of use and the increase represent substantial concerns, which are compounded by the results of telephone surveys indicating that up to $26 \%$ of OTC NSAID users take more than the recommended dose. ${ }^{1,3}$

\section{NSAID-associated gastrointestinal complications}

NSAID use has been associated with cardiovascular (CV), renal, and gastrointestinal (GI) complications, and certain patients are at increased risk. NSAID use results in small but consistent increases in the risk of $\mathrm{CV}$ events such as myocardial infarction, affected in part by dose and potency of cyclooxygenase-2 (COX-2) inhibition. ${ }^{4,5}$ NSAID use has also long been associated with kidney disease, ${ }^{6}$ resulting in both acute and chronic impairments in kidney function. ${ }^{7}$ These complications prompted the US Food and Drug Administration (FDA) to release a scientific statement in 2005 emphasizing "the importance of using the lowest effective dose for the shortest duration possible if treatment with an NSAID is warranted for an individual patient."

More common than CV and renal complications associated with NSAID use are NSAID-related GI events, which are among the most common drug-related side effects in the United States ${ }^{10,11}$ and occur in both prescription and OTC NSAID users. These complications include bleeding gastric or duodenal ulcers and, to a lesser extent, obstructions and perforations. ${ }^{12}$ In a retrospective analysis of a rheumatoid arthritis patient database published in 2000, OTC ibuprofen and naproxen users had a relative risk for serious GI complications of approximately 3.5 compared with NSAID nonusers, ${ }^{13}$ and it is estimated that $1 \%-2 \%$ of continuous NSAID users experience a clinically significant upper GI event per year. ${ }^{14-18}$ These findings represent a significant clinical concern, as patients taking NSAIDs experience a relative risk of upper GI bleeding and perforations of up to 4.7 compared with nonusers. ${ }^{19}$

GI complications are generally thought to be mediated primarily through inhibition of mucosal cyclooxygenase-1 (COX-1) and resultant suppression of prostaglandin production. ${ }^{20}$ However, COX-2 inhibition and other mechanisms, such as changes in the bacterial microbiome in the gut or the generation of free radicals, are also possibly involved. ${ }^{21,22}$ There is some question regarding the extent to which differential inhibition of COX-1 and -2 affects the GI risks associated with various NSAIDs. NSAIDs exhibit differential COX-1 and -2 inhibition and have been associated with different risks of GI and CV adverse events that vary among patients, ${ }^{20,23}$ but data sufficient to justify differences in labeling among NSAIDs in the United States have not been established. ${ }^{24,25}$

In contrast to the acute effects of NSAIDs on the GI tract, there is some evidence that NSAID use may reduce risks of GI cancers, including gastric, pancreatic, and colorectal cancers. ${ }^{26}$ For example, several studies have found that nonaspirin NSAID treatments are associated with decreased risk of gastric cancer ${ }^{27,28}$ and, in the case of celecoxib, increased regression of precancerous gastric lesions compared with placebo. ${ }^{29}$ However, further study is needed to better characterize these potentially protective effects. 


\section{Upper Gl complications}

It is often noted that potentially serious GI complications commonly develop with no clinical warning symptoms suggestive of ulcers or bleeding. However, although NSAID users report increased frequency of various symptoms including reflux, belching, bloating, and/or nausea compared with nonusers, ${ }^{30}$ these symptoms do not reliably indicate the presence of significant upper GI mucosal injury, ${ }^{31}$ which includes ulcers, bleeding, perforation, obstruction, and extensive erosions. A prospective observational study found that bleeding complications occurred without typical ulcer symptoms (epigastric pain or dyspepsia) in up to $80 \%$ of affected patients. ${ }^{32}$ In addition, a meta-analysis of studies performed before 1997 and from 1997-2008 found that, while the overall mortality rate from GI bleeds has fallen since the mid-1990s, NSAID users with upper GI bleeding or perforation exhibit a higher mortality rate from these injuries compared with nonusers with comparable clinical scenarios. ${ }^{33}$ Endoscopic techniques are frequently used to manage peptic ulcer bleeding, but little research has been done to investigate whether NSAID use impacts the rate of successful hemostasis following endoscopic therapy. A retrospective study of only 76 patients found no association between NSAIDs and failure of endoscopy therapy for the treatment of gastric ulcer-associated bleeding, but the sample size was small. ${ }^{34}$ Interestingly, a randomized controlled trial of 224 patients who developed ulcer complications following NSAID use found that use of a COX-2 selective NSAID (celecoxib) with no effect on platelet aggregation was associated with a lower risk of recurrent bleeding compared with PPI and nonselective NSAID co-therapy; however, both therapies conferred a significant risk of rebleeding. ${ }^{35}$ These results led to a recommendation by the American College of Physicians that patients with previous ulcer bleeding who require an NSAID be treated with "the combination of a PPI and a COX-2 inhibitor." 36

\section{Lower Gl complications}

The rate of lower GI complications resulting from NSAID use has not been as widely documented as that of upper GI damage, but such complications have been recognized for decades. ${ }^{37}$ These injuries include bleeding in the large and small bowel, strictures of the small bowel, or exacerbation of existing illnesses such as inflammatory bowel disease. ${ }^{38}$ While the incidence of lower GI injury associated with NSAID use is somewhat lower than that of upper GI injury, results from a 2003 prospective study of rheumatoid arthritis patients found that $0.9 \%$ of patients taking naproxen $500 \mathrm{mg}$ twice daily developed serious lower GI complications over a 1-year period, ${ }^{39}$ and a 2005 retrospective study of health records in Spain found that, while the greater incidence of upper GI events results in more fatalities overall, upper and lower GI events have similar mortality rates. ${ }^{40}$ Video capsule endoscopy assessment of the small bowel has allowed clinicians to better quantify NSAID-related small intestinal mucosal injury, ${ }^{41}$ as shown by a study that found that healthy volunteers who received either naproxen $500 \mathrm{mg}$ twice daily and omeprazole $20 \mathrm{mg}$ once daily or celecoxib $200 \mathrm{mg}$ twice daily for 2 weeks exhibited significantly more mucosal breaks compared with those receiving placebo. ${ }^{42}$ Slow-release diclofenac also resulted in new small intestinal mucosal injury compared with baseline after 7 days of use in almost three-quarters of healthy volunteers assessed via capsule endoscopy. ${ }^{43}$

It is hypothesized that asymptomatic small bowel mucosal injury may lead to occult blood loss over time, resulting in decreases in hemoglobin levels. Results from the CONDOR (celecoxib versus omeprazole and diclofenac in patients with Osteoarthritis and Rheumatoid arthritis) study, which compared celecoxib $200 \mathrm{mg}$ twice daily with diclofenac slow-release $75 \mathrm{mg}$ twice daily plus omeprazole (a PPI) $20 \mathrm{mg}$ once daily in arthritis patients at high risk of upper GI complications, support this concept. In that study, investigators found that, while upper GI events did not differ among treatment groups, use of diclofenac and omeprazole resulted in $3.4 \%$ of patients exhibiting a $\geq 2.0 \mathrm{~g} / \mathrm{L}$ decrease in hemoglobin over approximately 6 months in the absence of overt bleeding. ${ }^{44,45}$ This finding suggests that GI blood loss may have been more related to slow occult bleeding. ${ }^{46}$ Together, these studies suggest that lower bowel injuries should be taken into account when considering the risks of NSAID use and when considering managing long-term risk.

\section{Risks of NSAID-associated GI injuries over time}

The risk of NSAID-associated GI complications is dose dependent and remains linear over time, based on the results of randomized controlled trials. ${ }^{14,15}$ The 6-month Misoprostol Ulcer Complication Outcomes Safety Assessment (MUCOSA) study, which investigated the effects of misoprostol coadministration on GI complications associated with NSAID use, and the Vioxx Gastrointestinal Outcomes Research (VIGOR) study, which compared the GI risks of naproxen with rofecoxib, both found that the cumulative incidence of upper GI events in the nonselective NSAID treatment arms was linear over time (Figure 2)..$^{14,15,47}$ In addition, two 

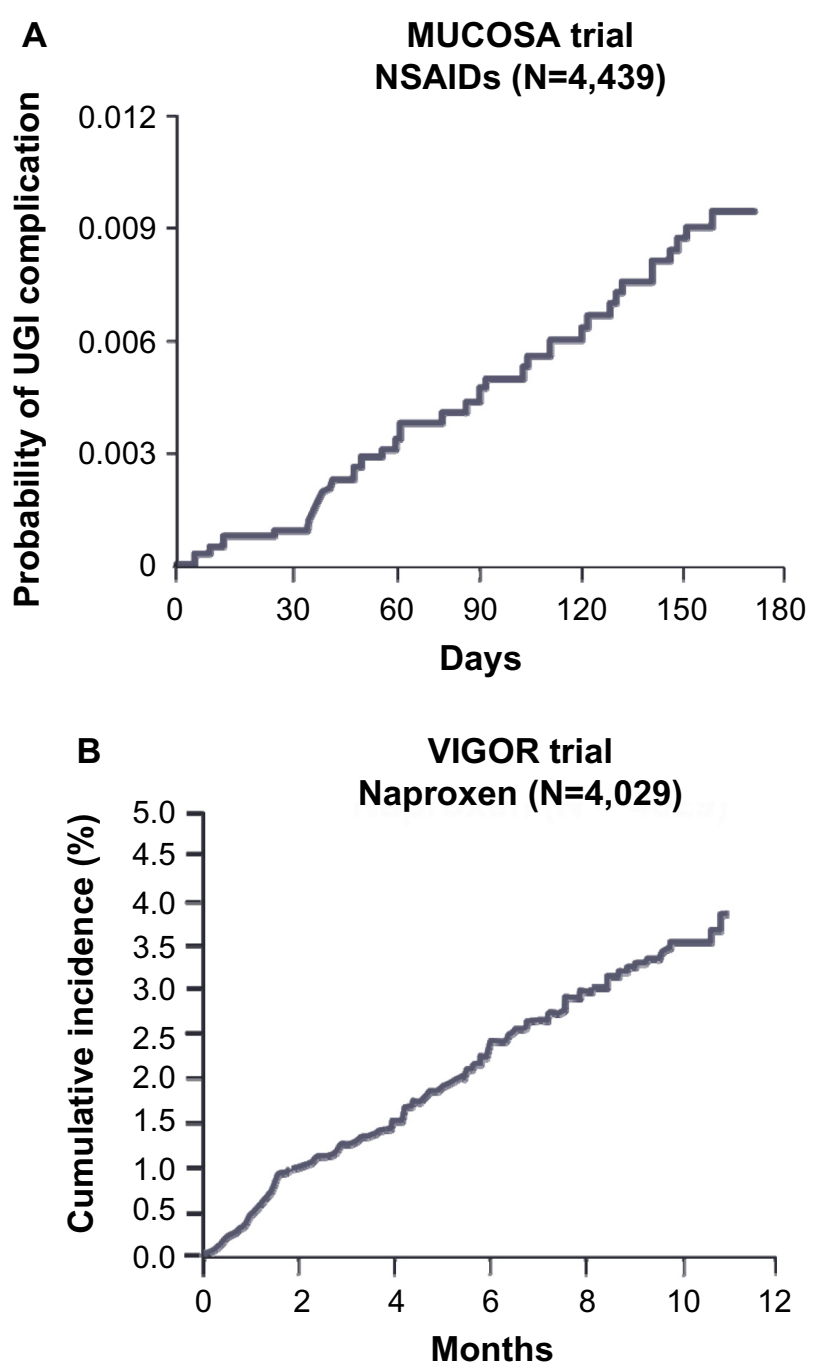

Figure 2 Incidence of UGI complications with increasing duration of NSAIDs in the MUCOSA and VIGOR trials.

Notes: The MUCOSA trial (A) evaluated the effects of misoprostol- co-administration with a variety of nonselective NSAIDs (eg, naproxen, ibuprofen, diclofenac, and others) on gastrointestinal complication rates. Reproduced from Silverstein FE, Graham DY, Senior JR, et al. Misoprostol reduces serious gastrointestinal complications in patients with rheumatoid arthritis receiving nonsteroidal anti-inflammatory drugs. A randomized, double-blind, placebo-controlled trial. Ann Intern Med. 1995; 123(4): 24I-249.14 The VIGOR trial (B) compared the gastrointestinal effects of naproxen and rofecoxib overtime. Reproduced from N Engl J Med, Bombardier C, Laine L, Reicin A, et al;VIGOR Study Group, Comparison of upper gastrointestinal toxicity of rofecoxib and naproxen in patients with rheumatoid arthritis. VIGOR Study Group. 2000;343(21):1520-1528. Copyright @2000 Massachusetts Medical Society. Reprinted with permission from Massachusetts Medical Society. ${ }^{15}$ In both trials, the incidence of upper gastrointestinal complications with NSAIDs was began early, linear, constant, and was present for the duration of NSAID exposure.

Abbreviations: MUCOSA, Misoprostol Ulcer Complication Outcomes Safety Assessment; NSAID, nonsteroidal anti-inflammatory drug; UGI, upper gastrointestinal; VIGOR, Vioxx Gastrointestinal Outcomes Research.

6-month, double-blind, prospective, randomized clinical trials investigating lower GI injury following NSAID use found that the rate of patients meeting the endpoint of a decrease in hemoglobin $>2 \mathrm{~g} / \mathrm{dL}$ was roughly constant over time. ${ }^{47}$ Confirming these results in a clinical practice setting was the Gastrointestinal Randomized Event and Safety Open-label
Non-steroidal anti-inflammatory drug Study (GI-REASONS), a randomized, prospective, open-label study comparing celecoxib with nonselective NSAIDs in osteoarthritis (OA) patients, which also found that the cumulative incidence of clinically significant upper and lower GI events was roughly linear over the 6-month trial period. ${ }^{18}$ Because GI complications associated with NSAID use are dose related and can occur at any time following exposure, ${ }^{32}$ several international societies, including the National Institute for Health and Care Excellence (NICE) in the United Kingdom, the American College of Gastroenterology, and the American College of Rheumatology (ACR), have recommended identification of risk factors and prophylaxis independent of the presence or absence of symptoms in patients with moderate-to-high risk of GI complications (Table 1). ${ }^{48-50}$

\section{Risk factors for NSAID-associated Gl injury}

A variety of patient characteristics are associated with increased risk for NSAID-related GI complications (Table 1). Patients with a history of GI injury are at higher risk for GI complications following NSAID use, ${ }^{14,51}$ and patients with renal failure who are on hemodialysis also exhibit increased risk of GI bleeding with NSAID use. ${ }^{52}$ Age is an important factor, with risk increasing with increasing age. As the absolute risk varies by age, a threshold of risk based on age is often suggested to be $>60$ years old. ${ }^{53,54}$ Patients taking high-dose NSAIDs and those taking NSAIDs with aspirin, even at low, CV-prevention doses ( $\leq 325 \mathrm{mg} /$ day), have elevated risks of GI events. ${ }^{55}$ Certain medications also increase the risk of GI injury when used concurrently with NSAIDs. For example, use of oral corticosteroids coadministered with NSAIDs is associated with an increase in the rate of GI complications as much as twofold compared with patients taking NSAIDs alone. ${ }^{55}$ Anticoagulants have been found to substantially increase the risk for elderly patients of developing ulcer

Table I Characteristics of patients with an elevated risk for NSAID-associated gastrointestinal complications

\section{Characteristics}

- Age $>60$ years $^{53,54}$

- Helicobacter pylori infection ${ }^{57}$

- Receiving hemodialysis ${ }^{52}$

- High-dose or multiple NSAID use ${ }^{55}$

- History of upper gastrointestinal injury ${ }^{14,51}$

- Anticoagulant use $\mathrm{e}^{58,59}$

- Oral corticosteroid use; prednisone $e^{55,60}$

- Selective serotonin reuptake inhibitor use $e^{61,62,64}$

Abbreviation: NSAID, nonsteroidal anti-inflammatory drug. 
bleeding when used with NSAIDs. ${ }^{56}$ Additionally, a Danish study of prescription and hospitalization records of patients ages 16 to 105 years found that anticoagulants and nonsalicylate NSAIDs taken concurrently increased upper GI bleeding more than anticoagulants taken with aspirin or acetaminophen. ${ }^{58}$ Furthermore, the increased risk of ulcer bleeding due to anticoagulant use may not be mitigated by gastroprotective agents. ${ }^{59}$ Selective serotonin reuptake inhibitors also increase risk of upper GI complications when used with NSAIDs, as several studies have shown that concurrent selective serotonin reuptake inhibitor and NSAID use results in a greater increase in the incidence of GI bleeding than the sum of their independent effects would suggest. ${ }^{61-64}$ These results suggest that caution should be used when considering prescribing NSAIDs to patients using these agents.

The limited awareness of risk factors results in many patients receiving inadequate preventative therapies. For example, a study of veterans prescribed NSAIDs over a 1 -year period showed that nearly three-quarters $(73 \%)$ of the patients with risk factors for NSAID-related upper GI injury were not receiving appropriate gastroprotective therapy based on evidence-based guidelines. ${ }^{65}$ In fact, prescription practices may frequently be inappropriate when a patient's GI and CV history are considered, according to results from a Spanish National Health System study conducted in 2011, which found that $74 \%$ of OA patients with elevated risk for GI and CV NSAID-related side effects were receiving nonselective NSAIDs or COX-2 selective NSAIDs. ${ }^{66}$ These data indicate that not only do NSAIDs represent heightened risks to some patients, but that awareness of the risk factors and of the use of preventative therapy for NSAID-related upper GI injury could be improved.

\section{Approaches to the prevention of GI injuries from NSAIDs PPIs and histamine-2 $(\mathrm{H} 2)$ receptor antagonists}

Coadministration of NSAIDs with PPIs is a well-documented and effective, although underutilized, approach to reduce endoscopic damage and control dyspeptic symptoms associated with the use of NSAIDs (Table 2). ${ }^{65,67-69}$ Infrequent side effects associated with PPIs have occurred; these may include an increased chance of pneumonia compared with nonusers, ${ }^{12,70}$ hypomagnesemia, ${ }^{71}$ and increased incidence of spine and hip fractures, ${ }^{72}$ as well as an increased chance of contracting Clostridium difficile-associated diarrhea compared with PPI-naïve patients. ${ }^{73} \mathrm{H} 2$ receptor antagonists $\left(\mathrm{H}_{2} \mathrm{RAs}\right)$,
Table 2 Gastroprotective strategies to prevent gastrointestinal complications associated with NSAID use

\begin{tabular}{|c|c|c|}
\hline $\begin{array}{l}\text { Preventative } \\
\text { strategy }\end{array}$ & $\begin{array}{l}\text { Gastroprotection } \\
\text { strategy }\end{array}$ & Disadvantages \\
\hline $\begin{array}{l}\text { Proton-pump } \\
\text { inhibitors }^{70-73}\end{array}$ & $\begin{array}{l}\text { Reduce secretion } \\
\text { of gastric acid }\end{array}$ & $\begin{array}{l}\text { Associated with } \\
\text { increased risk } \\
\text { of pneumonia, } \\
\text { hypomagnesemia, } \\
\text { Clostridium difficile- } \\
\text { associated diarrhea, } \\
\text { and spine and hip } \\
\text { fractures }\end{array}$ \\
\hline Misoprostol ${ }^{74,75}$ & $\begin{array}{l}\text { Synthetic prostaglandin } \\
\text { that counteracts } \\
\text { prostaglandin inhibition } \\
\text { by NSAIDs }\end{array}$ & $\begin{array}{l}\text { Gastrointestinal } \\
\text { discomfort, nausea, } \\
\text { and diarrhea; fetal } \\
\text { loss }\end{array}$ \\
\hline $\begin{array}{l}\text { Histamine-2 } \\
\text { receptor } \\
\text { agonists }^{\mathrm{a}, 70,76}\end{array}$ & $\begin{array}{l}\text { Reduce secretion } \\
\text { of gastric acids }\end{array}$ & $\begin{array}{l}\text { Increased risk of } \\
\text { pneumonia }\end{array}$ \\
\hline $\begin{array}{l}\text { COX-2 } \\
\text { inhibitors }\end{array}$ & $\begin{array}{l}\text { Selective for COX-2 } \\
\text { receptor, which } \\
\text { circumvents the inhibition } \\
\text { of gastroprotective } \\
\text { prostaglandins by COX-I }\end{array}$ & $\begin{array}{l}\text { Cardiovascular } \\
\text { complications } \\
\text { similar to those } \\
\text { associated with } \\
\text { other NSAIDs }\end{array}$ \\
\hline $\begin{array}{l}\text { Topical } \\
\text { formulations }^{78}\end{array}$ & $\begin{array}{l}\text { Lowers systemic drug } \\
\text { exposure to potentially } \\
\text { reduce risk }\end{array}$ & $\begin{array}{l}\text { Impractical for } \\
\text { systemic pain and } \\
\text { may be ineffective } \\
\text { for long-term pain } \\
\text { relief }\end{array}$ \\
\hline $\begin{array}{l}\text { Lower-dose oral } \\
\text { formulations }^{79-81}\end{array}$ & $\begin{array}{l}\text { Lowers systemic drug } \\
\text { exposure to reduce risk }\end{array}$ & $\begin{array}{l}\text { Limited efficacy } \\
\text { and safety data }\end{array}$ \\
\hline
\end{tabular}

Note: a Only effective as a protective agent at $300 \mathrm{mg}$ twice daily for ranitidine, $\geq 40 \mathrm{mg}$ twice daily for nizatidine, and $80 \mathrm{mg}$ total daily dose for famotidine.

Abbreviations: COX, cyclooxygenase; NSAID, nonsteroidal anti-inflammatory drug.

which inhibit acid secretion, have also been evaluated for reducing NSAID-associated complications. A meta-analysis of 14 trials found that $\mathrm{H}_{2} \mathrm{RAs}$ (eg, famotidine and ranitidine) were protective at high doses, but, at commonly prescribed doses, they reduced the risk of duodenal but not gastric ulcers. ${ }^{82}$ This was demonstrated in a 24-week study of patients requiring chronic NSAID treatment, which showed that coadministration of high-dose $(80 \mathrm{mg} /$ day) famotidine with ibuprofen $(2,400 \mathrm{mg} /$ day $)$ resulted in significantly fewer gastroduodenal ulcers compared with ibuprofen alone. ${ }^{76}$ Rare side effects associated with $\mathrm{H}_{2} \mathrm{RA}$ use include increased risk of pneumonia. ${ }^{68}$

\section{Misoprostol}

Co-prescribed misoprostol, a synthetic prostaglandin used to counteract the prostaglandin-inhibitory actions of NSAIDs, decreases NSAID-related upper GI complications by approximately $40 \%$ compared with NSAIDs alone. ${ }^{14,83}$ The singletablet combination therapy of diclofenac sodium-misoprostol 
was found to be an effective gastroprotective therapy measured by cost per life-year gained in a study in the Netherlands. ${ }^{84}$ Of note is that the single-tablet formulation may improve patient adherence, as nonadherence with multiple-pill therapeutic regimens increases the risk of GI events. ${ }^{69,85,86}$ Unfortunately, misoprostol is not always well tolerated due to diarrhea and abdominal pain, preventing continued use; lower doses of misoprostol with a lesser frequency of side effects may also be less effective at preventing GI events. ${ }^{74}$ Misoprostol is an abortifacient, contraindicating its use in women who are pregnant or may become pregnant (Table 2). ${ }^{75}$ Rebamipide is a cytoprotective anti-ulcer drug that stimulates prostaglandin production. At a dose of $100 \mathrm{mg}$ three times daily (TID), it was found to be significantly more effective in reducing rates of endoscopic gastric or duodenal ulcer compared with misoprostol $200 \mathrm{mg}$ TID in the Study of NSAID-induced GI Toxicity Prevention by Rebamipide and Misoprostol (STORM), a multicenter, 12-week, randomized controlled trial of patients using NSAIDs. Rebamipide is not approved for use in the United States. ${ }^{87}$

\section{COX-2 inhibitors}

COX-2 selective inhibitors are associated with less risk of GI injury than nonselective NSAIDs due to lesser inhibition of COX-1, which is involved in the maintenance of gastric mucosa integrity. COX-2 selective inhibitor use was associated with a decrease in the risk of symptomatic ulcers and clinically significant ulcer complications compared with nonselective NSAIDs, according to a 2007 meta-analysis. ${ }^{88}$ In the CONDOR study, while efficacy was similar, fewer patients treated with the COX-2 selective inhibitor celecoxib experienced reductions in hemoglobin or withdrew from the study due to adverse GI events compared with those treated with diclofenac plus omeprazole. ${ }^{44,45}$ However, use of COX-2 inhibitors at therapeutic doses may increase $\mathrm{CV}$ risks. ${ }^{77}$ Following an FDA warning about the $\mathrm{CV}$ risks of COX-2 inhibitors and all nonselective NSAIDs, and the voluntary withdrawals of rofecoxib and valdecoxib from the market, ${ }^{8,89}$ prescriptions for COX-2 inhibitors decreased by $12 \%$ and those for nonselective NSAIDs increased by $47 \%$ between 2003 and 2005 . However, this trend was not accompanied by an increase in prescriptions of gastroprotective co-therapies. ${ }^{90}$

\section{Enteric-coated NSAIDs}

While at least one study found that enteric-coated NSAIDs reduce upper GI events, ${ }^{91}$ most data indicate that entericcoated NSAIDs do not reduce incidence of upper GI events compared with other formulations. ${ }^{92-94}$ Interestingly, attempts to reduce upper GI symptoms through use of slow-release and enteric-coated formulations may hypothetically increase lower GI complications. ${ }^{95}$

\section{Topical NSAIDs}

Because NSAID-associated GI complications are dose dependent, development of formulations that lower systemic exposure while providing efficacious pain relief may reduce GI injury. Topical NSAID formulations can produce higher concentrations of drug in local tissue with very low systemic exposure as measured via plasma concentrations, ${ }^{96}$ and use of topical NSAIDs may be associated with fewer GI events (Table 2). ${ }^{97-101}$ Although topical NSAID formulations have been shown to be effective in treatment of acute pain, ${ }^{78}$ and for short-term use in treating chronic pain, there are conflicting results regarding whether topical NSAIDs provide effective long-term pain relief. ${ }^{102,103}$ Further study is necessary to determine the long-term benefits and risks of topical NSAID use.

\section{Lower-dose NSAID formulations}

New formulations of NSAIDs may reduce risks of adverse events by using lower doses while providing effective analgesia (Table 2). There is some evidence that some NSAIDs, such as diclofenac, could provide effective pain relief at lower doses than are currently used, assuming $80 \%$ inhibition of COX-2 is necessary for therapeutic efficacy. ${ }^{51}$ This would hypothetically provide effective pain relief with an improved GI safety profile due to lessened inhibition of COX-1. ${ }^{20}$

A diclofenac potassium liquid-filled capsule ${ }^{104}$ using a formulation designed to deliver diclofenac more rapidly than conventional tablets was approved by the FDA in 2009. ${ }^{105,106}$ Absorption of the liquid-filled capsules is faster than that of diclofenac potassium immediate-release tablets, and the capsules produce greater pain relief compared with placebo at lower doses of diclofenac ( $25 \mathrm{mg}$ four times daily) than are generally used $;^{79,105,107}$ however, it is unclear whether they produce more rapid or effective pain relief than other diclofenac formulations. Lower-dose capsules that contain finely milled, rapidly absorbed NSAID particles may also provide analgesia at lower systemic doses. ${ }^{80,81}$ Low-dose diclofenac capsules (18 mg or $35 \mathrm{mg}$ TID for mild-to-moderate pain) and indomethacin capsules $(20 \mathrm{mg}$ TID or $40 \mathrm{mg}$ two times daily or TID) containing fine-milled particles have been approved by the FDA for treatment of mild-to-moderate acute pain in adults $^{25,108}$ and have been found to provide effective relief of acute, postoperative pain in Phase III studies. ${ }^{80,81}$ Additionally, low-dose diclofenac (35 mg TID) has been shown to 
provide effective treatment of OA pain in a 12-week study and has been approved by the FDA for management of OArelated pain. ${ }^{109} \mathrm{~A}$ low-dose naproxen capsule was also found to effectively relieve postoperative dental pain in a Phase II study. ${ }^{110}$

\section{H. pylori}

Eradicating $H$. pylori may decrease GI risks in some NSAID users, which could reduce worldwide incidence of NSAID-related GI injury, as $H$. pylori affects up to $50 \%$ of the worldwide population. ${ }^{111}$ One systematic literature review found that $H$. pylori eradication in infected patients was as effective as the use of PPIs in preventing GI complications due to NSAID use $;^{57}$ however, another found that, although H. pylori eradication reduces risk, PPIs provided superior ulcer prevention. ${ }^{112}$ While it is unclear whether $H$. pylori eradication is as effective as other strategies, it may provide benefit to some patients.

\section{Nonpharmacologic therapies}

Another possibility for reducing the incidence of NSAID-associated GI complications is to reduce NSAID use through adoption of alternative therapies. While assessment of their effectiveness is challenging, therapies such as acupuncture and physical therapy/exercise may provide relief for some patients. While some randomized controlled trials have found acupuncture to be more effective for OA pain relief than sham treatments, a meta-analysis of eleven studies published between 1994 and 2006 found sufficiently heterogeneous results that the authors were unable to draw firm conclusions regarding acupuncture's efficacy. ${ }^{113}$ While significant results have been found for use of acupuncture, particularly for knee OA, ${ }^{114}$ the effect is generally small, and larger studies are needed. ${ }^{115}$ Exercise and physical therapy may also provide pain relief, as they have been found to improve pain and function in knee $\mathrm{OA},{ }^{116}$ may delay the need for surgical intervention, ${ }^{117}$ and may reduce the need for medication. ${ }^{118}$ Because of these results, the ACR has issued guidelines strongly recommending exercise for knee OA.$^{50}$ Unfortunately, the effect of exercise on knee OA may be short-term, and the extent of functional improvement is unclear. ${ }^{119}$ While many approaches for prevention of NSAIDassociated GI injury show effectiveness in some studies, practical considerations prevent their universal use.

\section{Cost-effectiveness}

The direct cost of preventative strategies to patients and payers and the absolute patient risk for GI complications are the key factors that influence cost-effectiveness. The relative cost of preventing a single complication is high in low-risk populations and is the basis of recommendations from the ACR and other health authorities that indicate that low-risk patients should not receive gastroprotective therapies. ${ }^{49,120,121}$ The picture becomes more complicated in patients with higher risk for GI injury; as risk increases, the associated costs of prescribing such therapies is increasingly offset by the escalating cumulative costs associated with the adverse events. Net costs/savings are driven by the additional procurement costs of the preventative therapy and the expected frequency of adverse events based on risk. ${ }^{122}$ Many studies have tried to evaluate costeffectiveness, but it is difficult to make decisions based on finances given that the cost of PPIs has dramatically declined and that PPIs are now available OTC. Additionally, cost-effectiveness studies do not always adequately take into account the impact of injury on quality of life. An economic model examining PPI use in three large randomized trials, weighted by quality of life, found that use of PPIs with either COX-2 selective inhibitors or nonselective NSAIDs was cost-effective in OA patients, even those at low risk of GI events, with the caveat that the mean age of participants was above 60 years and thus these patients may not be considered to be objectively low risk. ${ }^{123}$ These studies suggest that the economic picture of how to most cost-effectively decrease NSAID-associated GI injury is not yet clear and that, together, studies considering different risk pools are necessary to determine optimal management of patient subpopulations.

\section{Balancing risks}

The $\mathrm{CV}$ risks associated with NSAID use have received increased attention recently, such that the American Heart Association released a statement declaring that NSAID use should be "coupled with the realization that effective pain relief may come at the cost of a small but real increase in risk for cardiovascular or cerebrovascular complications." 9 In February 2014, the FDA reviewed the data surrounding the CV complications associated with NSAID use and determined that there were insufficient data to distinguish CV toxicity among individual NSAIDs, including COX-2 selective inhibitors and naproxen, and that this class of agents was associated with an increased risk of ischemic events. ${ }^{25}$ This attention to the risks associated with NSAIDs and the potential differences among specific NSAIDs represents a growing awareness about the complications associated with this class of drugs. 


\section{Conclusion}

GI mucosal injury associated with use of NSAIDs is a serious clinical concern, and studies suggest that the rate of complications does not decrease with duration of use. There are several strategies and NSAID drug product formulations that may be associated with decreased GI risk, but there is no one therapy that will provide optimal pain relief and decrease risk for all patients. Also, although nonpharmacological therapies have promise, often they have been inadequately studied compared with pharmacological therapies. Meanwhile, the high cost of GI events to the health care system and to patients' quality of life necessitates improvement in the risk-benefit profile of NSAIDs or development of alternative medications or therapies. In addition, the $\mathrm{CV}$ and renal side effects of NSAIDs must be considered alongside reducing the risk of GI complications. Optimally, developments in pain management will focus on tailoring therapies to the individual patient. Also, in addition to development of new therapies, improvements in patient and provider education and patient adherence are necessary to improve outcomes. Greater awareness of the short-term GI risks of NSAIDs, including potential overuse of OTC NSAIDs and more frequent use of gastroprotection, might have prevented the ulcer in the patient described in the case study at the beginning of this article.

\section{Acknowledgments}

Editorial support for this manuscript was provided by Jill See, PhD, and Colville Brown, MD, of AlphaBioCom LLC (King of Prussia, PA, USA). Funding for editorial support was provided by Iroko Pharmaceuticals, LLC (Philadelphia, PA, USA).

\section{Disclosure}

JLG has served as an advisory board attendee for Iroko Pharmaceuticals, LLC. BC has served as a consultant for Iroko Pharmaceuticals, LLC; Ritter Pharmaceuticals; Sanofi Pharmaceuticals; Sandoz Pharmaceuticals; and Sucampo, Inc. The authors report no other conflicts of interest in this work.

\section{References}

1. Wilcox CM, Cryer B, Triadafilopoulos G. Patterns of use and public perception of over-the-counter pain relievers: focus on nonsteroidal antiinflammatory drugs. J Rheumatol. 2005;32(11):2218-2224.

2. Zhou Y, Boudreau DM, Freedman AN. Trends in the use of aspirin and nonsteroidal anti-inflammatory drugs in the general U.S. population. Pharmacoepidemiol Drug Saf. 2014;23(1):43-50.

3. Goldstein JL, Lefkowith JB. Public misunderstanding of nonsteroidal antiinflammatory drug (NSAID)-mediated gastrointestinal (GI) toxicity: a serious potential health threat. Gastroenterology. 1998;114:A136.
4. Capone ML, Tacconelli S, Rodriguez LG, Patrignani P. NSAIDs and cardiovascular disease: transducing human pharmacology results into clinical read-outs in the general population. Pharmacol Rep. 2010;62(3):530-535.

5. García Rodríguez LA, Tacconelli S, Patrignani P. Role of dose potency in the prediction of risk of myocardial infarction associated with nonsteroidal anti-inflammatory drugs in the general population. J Am Coll Cardiol. 2008;52(20):1628-1636.

6. Harirforoosh S, Asghar W, Jamali F. Adverse effects of nonsteroidal antiinflammatory drugs: an update of gastrointestinal, cardiovascular and renal complications. J Pharm Pharm Sci. 2013;16(5):821-847.

7. Choudhury D, Ahmed Z. Drug-associated renal dysfunction and injury. Nat Clin Pract Nephrol. 2006;2(2):80-91.

8. Public Health Advisory - FDA Announces Important Changes and Additional Warnings for COX-2 Selective and Non-Selective Non-Steroidal AntiInflammatory Drugs (NSAIDs) [webpage on the Internet]. Silver Spring, MD: US Food and Drug Administration; 2005 [updated August 16, 2013; accessed October 10, 2014]. Available from: http://www.fda.gov/Drugs/DrugSafety/PostmarketDrugSafetyInformationforPatientsandProviders/ucm150314.htm. Accessed October 10, 2014.

9. Antman EM, Bennett JS, Daugherty A, Furberg C, Roberts H, Taubert KA; American Heart Association. Use of nonsteroidal antiinflammatory drugs: an update for clinicians: a scientific statement from the American Heart Association. Circulation. 2007;115(12):1634-1642.

10. Butt JH, Barthel JS, Moore RA. Clinical spectrum of the upper gastrointestinal effects of nonsteroidal anti-inflammatory drugs. Natural history, symptomatology, and significance. Am J Med. 1988;84(2A):5-14.

11. Fries J. Toward an understanding of NSAID-related adverse events: the contribution of longitudinal data. Scand J Rheumatol Suppl. 1996;102:3-8.

12. de Jager CP, Wever PC, Gemen EF, et al. Proton pump inhibitor therapy predisposes to community-acquired Streptococcus pneumoniae pneumonia. Aliment Pharmacol Ther. 2012;36(10):941-949.

13. Singh G. Gastrointestinal complications of prescription and over-the-counter nonsteroidal anti-inflammatory drugs: a view from the ARAMIS database. Arthritis, Rheumatism, and Aging Medical Information System. Am J Ther. 2000;7(2):115-121.

14. Silverstein FE, Graham DY, Senior JR, et al. Misoprostol reduces serious gastrointestinal complications in patients with rheumatoid arthritis receiving nonsteroidal anti-inflammatory drugs. A randomized, double-blind, placebo-controlled trial. Ann Intern Med. 1995;123(4):241-249.

15. Bombardier C, Laine L, Reicin A, et al; VIGOR Study Group. Comparison of upper gastrointestinal toxicity of rofecoxib and naproxen in patients with rheumatoid arthritis. VIGOR Study Group. $N$ Engl J Med. 2000;343(21):1520-1528.

16. Silverstein FE, Faich G, Goldstein JL, et al. Gastrointestinal toxicity with celecoxib vs nonsteroidal anti-inflammatory drugs for osteoarthritis and rheumatoid arthritis: the CLASS study: A randomized controlled trial. Celecoxib Long-term Arthritis Safety Study. JAMA. 2000;284(10): 1247-1255.

17. Laine L, Bombardier C, Hawkey CJ, et al. Stratifying the risk of NSAID-related upper gastrointestinal clinical events: results of a double-blind outcomes study in patients with rheumatoid arthritis. Gastroenterology. 2002;123(4):1006-1012.

18. Cryer B, Li C, Simon LS, Singh G, Stillman MJ, Berger MF. GI-REASONS: a novel 6-month, prospective, randomized, open-label, blinded endpoint (PROBE) trial. Am J Gastroenterol. 2013;108(3):392-400.

19. García Rodríguez LA, Jick H. Risk of upper gastrointestinal bleeding and perforation associated with individual non-steroidal anti-inflammatory drugs. Lancet. 1994;343(8900):769-772.

20. Warner TD, Giuliano F, Vojnovic I, Bukasa A, Mitchell JA, Vane JR. Nonsteroid drug selectivities for cyclo-oxygenase-1 rather than cyclooxygenase-2 are associated with human gastrointestinal toxicity: a full in vitro analysis. Proc Natl Acad Sci U S A. 1999;96(13): 7563-7568. 
21. Wallace JL. Prostaglandins, NSAIDs, and gastric mucosal protection: why doesn't the stomach digest itself? Physiol Rev. 2008;88(4): 1547-1565.

22. Lanas A, Scarpignato C. Microbial flora in NSAID-induced intestinal damage: a role for antibiotics? Digestion. 2006;73 Suppl 1:136-150.

23. Bruno A, Tacconelli S, Patrignani P. Variability in the response to non-steroidal anti-inflammatory drugs: mechanisms and perspectives. Basic Clin Pharmacol Toxicol. 2014;114(1):56-63.

24. Celebrex ${ }^{\circledR}$ (celecoxib) [package insert]. New York, NY: Pfizer; 2008.

25. O'Riordan M. FDA Advisory Panel Votes Against CV Safety Claim for Naproxen [webpage on the Internet]. New York, NY: Medscape; 2014. Available from: http://www.medscape.com/viewarticle/820470. Accessed May 14, 2014.

26. Sahin IH, Hassan MM, Garrett CR. Impact of non-steroidal antiinflammatory drugs on gastrointestinal cancers: current state-of-the science. Cancer Lett. 2014;345(2):249-257.

27. Lindblad M, Lagergren J, García Rodríguez LA. Nonsteroidal antiinflammatory drugs and risk of esophageal and gastric cancer. Cancer Epidemiol Biomarkers Prev. 2005;14(2):444-450.

28. Sørensen HT, Friis S, Nørgård B, et al. Risk of cancer in a large cohort of nonaspirin NSAID users: a population-based study. Br J Cancer. 2003;88(11):1687-1692.

29. Wong BC, Zhang L, Ma JL, et al. Effects of selective COX-2 inhibitor and Helicobacter pylori eradication on precancerous gastric lesions Gut. 2012;61(6):812-818.

30. Sostres C, Gargallo CJ, Lanas A. Nonsteroidal anti-inflammatory drugs and upper and lower gastrointestinal mucosal damage. Arthritis Res Ther. 2013;15 Suppl 3:S3.

31. Armstrong CP, Blower AL. Non-steroidal anti-inflammatory drugs and life threatening complications of peptic ulceration. Gut. 1987;28(5):527-532.

32. Singh G, Ramey DR, Morfeld D, Shi H, Hatoum HT, Fries JF. Gastrointestinal tract complications of nonsteroidal anti-inflammatory drug treatment in rheumatoid arthritis. A prospective observational cohort study. Arch Intern Med. 1996;156(14):1530-1536.

33. Straube S, Tramèr MR, Moore RA, Derry S, McQuay HJ. Mortality with upper gastrointestinal bleeding and perforation: effects of time and NSAID use. BMC Gastroenterol. 2009;9:41.

34. Siva R, Al Zubaidi G, Masoud AK, Nihar M. Predictive factors for failure of endoscopic management therapy in peptic ulcer bleeding. Saudi J Gastroenterol. 2002;8(1):17-21.

35. Lai KC, Chu KM, Hui WM, et al. Celecoxib compared with lansoprazole and naproxen to prevent gastrointestinal ulcer complications. Am J Med. 2005;118(11):1271-1278.

36. Barkun AN, Bardou M, Kuipers EJ, et al; International Consensus Upper Gastrointestinal Bleeding Conference Group. International consensus recommendations on the management of patients with nonvariceal upper gastrointestinal bleeding. Ann Intern Med. 2010;152(2):101-113.

37. Langman MJ, Morgan L, Worrall A. Use of anti-inflammatory drugs by patients admitted with small or large bowel perforations and haemorrhage. Br Med J (Clin Res Ed). 1985;290(6465):347-349.

38. Bjorkman D. Nonsteroidal anti-inflammatory drug-associated toxicity of the liver, lower gastrointestinal tract, and esophagus. Am J Med. 1998;105(5A):17S-21S

39. Laine L, Connors LG, Reicin A, et al. Serious lower gastrointestinal clinical events with nonselective NSAID or coxib use. Gastroenterology. 2003;124(2):288-292.

40. Lanas A, Perez-Aisa MA, Feu F, et al; Investigators of the Asociación Española de Gastroenterología (AEG). A nationwide study of mortality associated with hospital admission due to severe gastrointestinal events and those associated with nonsteroidal antiinflammatory drug use. $\mathrm{Am}$ J Gastroenterol. 2005;100(8):1685-1693.

41. Chan FK, Cryer B, Goldstein JL, et al. A novel composite endpoint to evaluate the gastrointestinal (GI) effects of nonsteroidal antiinflammatory drugs through the entire GI tract. $J$ Rheumatol. 2010;37(1): $167-174$.
42. Goldstein JL, Eisen GM, Lewis B, Gralnek IM, Zlotnick S, Fort JG; Investigators. Video capsule endoscopy to prospectively assess small bowel injury with celecoxib, naproxen plus omeprazole, and placebo. Clin Gastroenterol Hepatol. 2005;3(2):133-141.

43. Maiden L, Thjodleifsson B, Theodors A, Gonzalez J, Bjarnason I. A quantitative analysis of NSAID-induced small bowel pathology by capsule enteroscopy. Gastroenterology. 2005;128(5):1172-1178.

44. Chan FK, Lanas A, Scheiman J, Berger MF, Nguyen H, Goldstein JL. Celecoxib versus omeprazole and diclofenac in patients with osteoarthritis and rheumatoid arthritis (CONDOR): a randomised trial. Lancet. 2010;376(9736):173-179.

45. Kellner HL, Li C, Essex MN. Celecoxib and diclofenac plus omeprazole are similarly effective in the treatment of arthritis in patients at high GI risk in the CONDOR Trial. Open Rheumatol J. 2013;7:96-100.

46. Bowen B, Yuan Y, James C, Rashid F, Hunt RH. Time course and pattern of blood loss with ibuprofen treatment in healthy subjects. Clin Gastroenterol Hepatol. 2005;3(11):1075-1082.

47. Goldstein JL, Chan FK, Lanas A, et al. Haemoglobin decreases in NSAID users over time: an analysis of two large outcome trials. Aliment Pharmacol Ther. 2011;34(7):808-816.

48. Conaghan PG, Dickson J, Grant RL; Guideline Development Group. Care and management of osteoarthritis in adults: summary of NICE guidance. BMJ. 2008;336(7642):502-503.

49. Lanza FL, Chan FK, Quigley EM; Practice Parameters Committee of the American College of Gastroenterology. Guidelines for prevention of NSAID-related ulcer complications. Am J Gastroenterol. 2009;104(3): 728-738.

50. Hochberg MC, Altman RD, April KT, et al; American College of Rheumatology. American College of Rheumatology 2012 recommendations for the use of nonpharmacologic and pharmacologic therapies in osteoarthritis of the hand, hip, and knee. Arthritis Care Res (Hoboken). 2012;64(4):465-474.

51. Van Hecken A, Schwartz JI, Depré M, et al. Comparative inhibitory activity of rofecoxib, meloxicam, diclofenac, ibuprofen, and naproxen on COX-2 versus COX-1 in healthy volunteers. J Clin Pharmacol. 2000;40(10):1109-1120.

52. Jankovic SM, Aleksic J, Rakovic S, et al. Nonsteroidal antiinflammatory drugs and risk of gastrointestinal bleeding among patients on hemodialysis. J Nephrol. 2009;22(4):502-507.

53. Fries JF, Williams CA, Bloch DA, Michel BA. Nonsteroidal antiinflammatory drug-associated gastropathy: incidence and risk factor models. Am J Med. 1991;91(3):213-222.

54. Hernández-Díaz S, Rodríguez LA. Association between nonsteroidal anti-inflammatory drugs and upper gastrointestinal tract bleeding/perforation: an overview of epidemiologic studies published in the 1990s. Arch Intern Med. 2000;160(14):2093-2099.

55. Garcia Rodríguez LA, Hernández-Díaz S. The risk of upper gastrointestinal complications associated with nonsteroidal anti-inflammatory drugs, glucocorticoids, acetaminophen, and combinations of these agents. Arthritis Res. 2001;3(2):98-101.

56. Shorr RI, Ray WA, Daugherty JR, Griffin MR. Concurrent use of nonsteroidal anti-inflammatory drugs and oral anticoagulants places elderly persons at high risk for hemorrhagic peptic ulcer disease. Arch Intern Med. 1993;153(14):1665-1670.

57. Leontiadis GI, Sreedharan A, Dorward S, et al. Systematic reviews of the clinical effectiveness and cost-effectiveness of proton pump inhibitors in acute upper gastrointestinal bleeding. Health Technol Assess. 2007;11(51):iii-iv, 1-164.

58. Johnsen SP, Sørensen HT, Mellemkjoer L, et al. Hospitalisation for upper gastrointestinal bleeding associated with use of oral anticoagulants. Thromb Haemost. 2001;86(2):563-568.

59. Lanas A, García-Rodríguez LA, Arroyo MT, et al; Investigators of the Asociación Española de Gastroenterología (AEG). Effect of antisecretory drugs and nitrates on the risk of ulcer bleeding associated with nonsteroidal anti-inflammatory drugs, antiplatelet agents, and anticoagulants. Am J Gastroenterol. 2007;102(3):507-515. 
60. Masclee GM, Valkhoff VE, van Soest EM, et al. Cyclo-oxygenase-2 inhibitors or nonselective NSAIDs plus gastroprotective agents: what to prescribe in daily clinical practice? Aliment Pharmacol Ther. 2013;38(2):178-189.

61. de Abajo FJ, Rodríguez LA, Montero D. Association between selective serotonin reuptake inhibitors and upper gastrointestinal bleeding: population based case-control study. BMJ. 1999;319(7217): 1106-1109.

62. de Jong JC, van den Berg PB, Tobi H, de Jong-van den Berg LT. Combined use of SSRIs and NSAIDs increases the risk of gastrointestinal adverse effects. Br J Clin Pharmacol. 2003;55(6):591-595.

63. Loke YK, Trivedi AN, Singh S. Meta-analysis: gastrointestinal bleeding due to interaction between selective serotonin uptake inhibitors and non-steroidal anti-inflammatory drugs. Aliment Pharmacol Ther. 2008;27(1):31-40.

64. Helin-Salmivaara A, Huttunen T, Grönroos JM, Klaukka T, Huupponen R. Risk of serious upper gastrointestinal events with concurrent use of NSAIDs and SSRIs: a case-control study in the general population. Eur J Clin Pharmacol. 2007;63(4):403-408.

65. Abraham NS, El-Serag HB, Johnson ML, et al. National adherence to evidence-based guidelines for the prescription of nonsteroidal antiinflammatory drugs. Gastroenterology. 2005;129(4):1171-1178.

66. Lanas A, Garcia-Tell G, Armada B, Oteo-Alvaro A. Prescription patterns and appropriateness of NSAID therapy according to gastrointestinal risk and cardiovascular history in patients with diagnoses of osteoarthritis. BMC Med. 2011;9:38.

67. Smalley W, Stein CM, Arbogast PG, Eisen G, Ray WA, Griffin M. Underutilization of gastroprotective measures in patients receiving nonsteroidal antiinflammatory drugs. Arthritis Rheum. 2002;46(8):2195-2200.

68. Sturkenboom MC, Burke TA, Tangelder MJ, Dieleman JP, Walton S, Goldstein JL. Adherence to proton pump inhibitors or H2-receptor antagonists during the use of non-steroidal anti-inflammatory drugs. Aliment Pharmacol Ther. 2003;18(11-12):1137-1147.

69. Goldstein JL, Howard KB, Walton SM, McLaughlin TP, Kruzikas DT. Impact of adherence to concomitant gastroprotective therapy on nonsteroidal-related gastroduodenal ulcer complications. Clin Gastroenterol Hepatol. 2006;4(11):1337-1345.

70. Eom CS, Jeon CY, Lim JW, Cho EG, Park SM, Lee KS. Use of acidsuppressive drugs and risk of pneumonia: a systematic review and meta-analysis. CMAJ. 2011;183(3):310-319.

71. Hess MW, Hoenderop JG, Bindels RJ, Drenth JP. Systematic review: hypomagnesaemia induced by proton pump inhibition. Aliment Pharmacol Ther. 2012;36(5):405-413.

72. Yu EW, Bauer SR, Bain PA, Bauer DC. Proton pump inhibitors and risk of fractures: a meta-analysis of 11 international studies. Am J Med. 2011;124(6):519-526

73. Janarthanan S, Ditah I, Adler DG, Ehrinpreis MN. Clostridium difficileassociated diarrhea and proton pump inhibitor therapy: a meta-analysis. Am J Gastroenterol. 2012;107(7):1001-1010.

74. Rostom A, Dube C, Wells G, et al. Prevention of NSAID-induced gastroduodenal ulcers. Cochrane Database Syst Rev. 2002;(4): CD002296.

75. Tang OS, Gemzell-Danielsson K, Ho PC. Misoprostol: pharmacokinetic profiles, effects on the uterus and side-effects. Int $J$ Gynaecol Obstet. 2007;99 Suppl 2:S160-S167.

76. Laine L, Kivitz AJ, Bello AE, Grahn AY, Schiff MH, Taha AS. Doubleblind randomized trials of single-tablet ibuprofen/high-dose famotidine vs. ibuprofen alone for reduction of gastric and duodenal ulcers. Am J Gastroenterol. 2012;107(3):379-386.

77. McGettigan P, Henry D. Cardiovascular risk with non-steroidal antiinflammatory drugs: systematic review of population-based controlled observational studies. PLoS Med. 2011;8(9):e1001098.

78. Massey T, Derry S, Moore RA, McQuay HJ. Topical NSAIDs for acute pain in adults. Cochrane Database Syst Rev. 2010;(6):CD007402.

79. Lissy M, Scallion R, Stiff DD, Moore K. Pharmacokinetic comparison of an oral diclofenac potassium liquid-filled soft gelatin capsule with a diclofenac potassium tablet. Expert Opin Pharmacother. 2010;11(5): 701-708.
80. Gibofsky A, Silberstein S, Argoff C, Daniels S, Jensen S, Young CL. Lower-dose diclofenac submicron particle capsules provide early and sustained acute patient pain relief in a phase 3 study. Postgrad Med. 2013;125(5):130-138.

81. Altman R, Daniels S, Young CL. Indomethacin submicron particle capsules provide effective pain relief in patients with acute pain: a phase 3 study. Phys Sportsmed. 2013;41(4):7-15.

82. Rostom A, Wells G, Tugwell P, Welch V, Dubé C, McGowan J. The prevention of chronic NSAID induced upper gastrointestinal toxicity: a Cochrane collaboration metaanalysis of randomized controlled trials. J Rheumatol. 2000;27(9):2203-2214.

83. Bocanegra TS, Weaver AL, Tindall EA, et al. Diclofenac/misoprostol compared with diclofenac in the treatment of osteoarthritis of the knee or hip: a randomized, placebo controlled trial. Arthrotec Osteoarthritis Study Group. J Rheumatol. 1998;25(8):1602-1611.

84. Al MJ, Maniadakis N, Grijseels EW, Janssen M. Costs and effects of various analgesic treatments for patients with rheumatoid arthritis and osteoarthritis in the Netherlands. Value Health. 2008;11(4):589-599.

85. Sturkenboom MC, Burke TA, Dieleman JP, Tangelder MJ, Lee F, Goldstein JL. Underutilization of preventive strategies in patients receiving NSAIDs. Rheumatology (Oxford). 2003;42 Suppl 3):iii23-31.

86. Lanas A, Polo-Tomás M, Roncales P, Gonzalez MA, Zapardiel J. Prescription of and adherence to non-steroidal anti-inflammatory drugs and gastroprotective agents in at-risk gastrointestinal patients. Am J Gastroenterol. 2012;107(5):707-714.

87. Park SH, Cho CS, Lee OY, et al. Comparison of prevention of NSAID-induced gastrointestinal complications by rebamipide and misoprostol: a randomized, multicenter, controlled trial-STORM STUDY. $J$ Clin Biochem Nutr. 2007;40(2):148-155.

88. Rostom A, Muir K, Dubé C, et al. Gastrointestinal safety of cyclooxygenase-2 inhibitors: a Cochrane Collaboration systematic review. Clin Gastroenterol Hepatol. 2007;5(7):818-828, 828. e1-e5.

89. US Food and Drug Administration. FDA issues public health advisory on Vioxx as its manufacturer voluntarily withdraws the product [press release]. Silver Spring, MD: US Food and Drug Administration; 2004 [September 30] [updated April 2, 2013; cited October 10, 2014]. Available from: http://www.fda.gov/NewsEvents/Newsroom/ PressAnnouncements/2004/ucm108361.htm. Accessed October 2, 2014.

90. Greenberg JD, Fisher MC, Kremer J, et al; CORRONA Investigators. The COX-2 inhibitor market withdrawals and prescribing patterns by rheumatologists in patients with gastrointestinal and cardiovascular risk. Clin Exp Rheumatol. 2009;27(3):395-401.

91. Caldwell JR, Roth SH. A double blind study comparing the efficacy and safety of enteric coated naproxen to naproxen in the management of NSAID intolerant patients with rheumatoid arthritis and osteoarthritis. Naproxen EC Study Group. J Rheumatol. 1994;21(4):689-695.

92. Le Loët X, Dreiser RL, Le Gros V, Febvre N. Therapeutic equivalence of diclofenac sustained-released $75 \mathrm{mg}$ tablets and diclofenac entericcoated $50 \mathrm{mg}$ tablets in the treatment of painful osteoarthritis. Int J Clin Pract. 1997;51(6):389-393.

93. Khong TK, Downing ME, Ellis R, Patchett I, Trayner J, Miller AJ. The efficacy and tolerability of enteric and non-enteric coated naproxen tablets: a double-blind study in patients with osteoarthritis. Curr Med Res Opin. 1991;12(8):540-546.

94. Bellamy N, Beaulieu A, Bombardier C, et al. Efficacy and tolerability of enteric-coated naproxen in the treatment of osteoarthritis and rheumatoid arthritis: a double-blind comparison with standard naproxen followed by an open-label trial. Curr Med Res Opin. 1992;12(10):640-651.

95. Davies NM. Sustained release and enteric coated NSAIDs: are they really GI safe? J Pharm Pharm Sci. 1999;2(1):5-14.

96. Rolf C, Engström B, Beauchard C, Jacobs LD, Le Liboux A. Intra-articular absorption and distribution of ketoprofen after topical plaster application and oral intake in 100 patients undergoing knee arthroscopy. Rheumatology (Oxford). 1999;38(6):564-567. 
97. Martens M. Efficacy and tolerability of a topical NSAID patch (local action transcutaneous flurbiprofen) and oral diclofenac in the treatment of soft-tissue rheumatism. Clin Rheumatol. 1997;16(1):25-31.

98. Tugwell PS, Wells GA, Shainhouse JZ. Equivalence study of a topical diclofenac solution (pennsaid) compared with oral diclofenac in symptomatic treatment of osteoarthritis of the knee: a randomized controlled trial. J Rheumatol. 2004;31(10):2002-2012.

99. Simon LS, Grierson LM, Naseer Z, Bookman AA, Zev Shainhouse J. Efficacy and safety of topical diclofenac containing dimethyl sulfoxide (DMSO) compared with those of topical placebo, DMSO vehicle and oral diclofenac for knee osteoarthritis. Pain. 2009;143(3):238-245.

100. Brewer AR, Pierchala LA, Yanchick JK, Magelli M, Rovati S. Gastrointestinal tolerability of diclofenac epolamine topical patch 1.3\%: a pooled analysis of 14 clinical studies. Postgrad Med. 2011;123(4):168-176.

101. Peniston JH, Gold MS, Wieman MS, Alwine LK. Long-term tolerability of topical diclofenac sodium $1 \%$ gel for osteoarthritis in seniors and patients with comorbidities. Clin Interv Aging. 2012;7:517-523.

102. Lin J, Zhang W, Jones A, Doherty M. Efficacy of topical non-steroidal anti-inflammatory drugs in the treatment of osteoarthritis: meta-analysis of randomised controlled trials. BMJ. 2004;329(7461):324.

103. Rother M, Lavins BJ, Kneer W, Lehnhardt K, Seidel EJ, Mazgareanu S. Efficacy and safety of epicutaneous ketoprofen in Transfersome (IDEA-033) versus oral celecoxib and placebo in osteoarthritis of the knee: multicentre randomised controlled trial. Ann Rheum Dis 2007;66(9):1178-1183.

104. Zipsor ${ }^{\circledR}$ (diclofenac potassium) [package insert]. Newport, KY: Xanodyne Pharmaceuticals, Inc.; 2009.

105. Daniels SE, Baum DR, Clark F, Golf MH, McDonnell ME, Boesing SE. Diclofenac potassium liquid-filled soft gelatin capsules for the treatment of postbunionectomy pain. Curr Med Res Opin. 2010;26(10):2375-2384.

106. Hersh EV, Levin LM, Adamson D, et al. Dose-ranging analgesic study of Prosorb diclofenac potassium in postsurgical dental pain. Clin Ther. 2004;26(8):1215-1227.

107. Kowalski M, Stoker DG, Bon C, Moore KA, Boesing SE. A pharmacokinetic analysis of diclofenac potassium soft-gelatin capsule in patients after bunionectomy. Am J Ther. 2010;17(5):460-468.

108. Bello AE. DUEXIS $\left({ }^{\circledR}\right)$ (ibuprofen $800 \mathrm{mg}$, famotidine $26.6 \mathrm{mg}$ ): a new approach to gastroprotection for patients with chronic pain and inflammation who require treatment with a nonsteroidal anti-inflammatory drug. Ther Adv Musculoskelet Dis. 2012;4(5):327-339.

109. Zorvolex Highlights of Prescribing Information. Available from: https:// www.zorvolex.com/wp-content/uploads/2013/12/Zor volex_Approved_ PI.pdf. Accessed August 29, 2014.
110. Young CL, Strand V, Altman R, Daniels S. A phase 2 study of naproxen submicron particle capsules in patients with post-surgical dental pain. Adv Ther. 2013;30(10):885-896.

111. Czinn SJ. Helicobacter pylori infection: detection, investigation, and management. J Pediatr. 2005;146(Suppl 3):S21-S26.

112. Vergara M, Catalán M, Gisbert JP, Calvet X. Meta-analysis: role of Helicobacter pylori eradication in the prevention of peptic ulcer in NSAID users. Aliment Pharmacol Ther. 2005;21(12):1411-1418.

113. Manheimer E, Linde K, Lao L, Bouter LM, Berman BM. Meta-analysis: acupuncture for osteoarthritis of the knee. Ann Intern Med. 2007;146(12):868-877.

114. Kwon YD, Pittler MH, Ernst E. Acupuncture for peripheral joint osteoarthritis: a systematic review and meta-analysis. Rheumatology (Oxford). 2006;45(11):1331-1337.

115. Manheimer E, Cheng K, Linde K, et al. Acupuncture for peripheral joint osteoarthritis. Cochrane Database Syst Rev. 2010;(1):CD001977.

116. Thomas KS, Muir KR, Doherty M, Jones AC, O’Reilly SC, Bassey EJ. Home based exercise programme for knee pain and knee osteoarthritis: randomised controlled trial. BMJ. 2002;325(7367):752.

117. Deyle GD, Henderson NE, Matekel RL, Ryder MG, Garber MB, Allison SC. Effectiveness of manual physical therapy and exercise in osteoarthritis of the knee. A randomized, controlled trial. Ann Intern Med. 2000;132(3):173-181.

118. Deyle GD, Allison SC, Matekel RL, et al. Physical therapy treatment effectiveness for osteoarthritis of the knee: a randomized comparison of supervised clinical exercise and manual therapy procedures versus a home exercise program. Phys Ther. 2005;85(12):1301-1317.

119. Fransen M, McConnell S. Land-based exercise for osteoarthritis of the knee: a metaanalysis of randomized controlled trials. J Rheumatol. 2009;36(6):1109-1117.

120. Scheiman JM. The use of proton pump inhibitors in treating and preventing NSAID-induced mucosal damage. Arthritis Res Ther. 2013; 15 Suppl 3:S5.

121. [No authors listed]. Recommendations for the medical management of osteoarthritis of the hip and knee: 2000 update. American College of Rheumatology Subcommittee on Osteoarthritis Guidelines. Arthritis Rheum. 2000;43(9):1905-1915.

122. Rahme E, Joseph L, Kong SX, Watson DJ, LeLorier J. Cost of prescribed NSAID-related gastrointestinal adverse events in elderly patients. Br J Clin Pharmacol. 2001;52(2):185-192.

123. Latimer N, Lord J, Grant RL, O’Mahony R, Dickson J, Conaghan PG; National Institute for Health and Clinical Excellence Osteoarthritis Guideline Development Group. Cost effectiveness of COX 2 selective inhibitors and traditional NSAIDs alone or in combination with a proton pump inhibitor for people with osteoarthritis. BMJ. 2009;339: b2538.

Drug, Healthcare and Patient Safety

\section{Publish your work in this journal}

Drug, Healthcare and Patient Safety is an international, peer-reviewed open-access journal exploring patient safety issues in the healthcare continuum from diagnostic and screening interventions through to treatment, drug therapy and surgery. The journal is characterized by the rapid reporting of reviews, original research, clinical, epidemiological and

post-marketing surveillance studies, risk management, health literacy and educational programs across all areas of healthcare delivery. The manuscript management system is completely online and includes a very quick and fair peer-review system. Visit http://www.dovepress.com/ testimonials.php to read real quotes from published authors. 